\title{
Debunking the Myth of the
}

Volunteers: Transnational

Volunteering in the Nazi Waffen-

SS Officer Corps during the

\section{Second World War}

\section{Journal Article}

Author(s):

Gutmann, Martin (D)

Publication date:

2013-11

\section{Permanent link:}

https://doi.org/10.3929/ethz-b-000319670

\section{Rights / license:}

In Copyright - Non-Commercial Use Permitted

Originally published in:

Contemporary European History 22(4), https://doi.org/10.1017/s0960777313000374 


\title{
Debunking the Myth of the
}

\section{Volunteers: Transnational}

\section{Volunteering in the Nazi}

\section{Waffen-SS Officer Corps}

\section{during the Second World War}

\author{
MARTIN G U T M A N N
}

\begin{abstract}
This article explores the pre-war background of the Swiss, Swedish and Danish men who volunteered for the Nazi Waffen-SS combat formation during the Second World War. Through a detailed biographical examination of officer corps volunteers, this article contradicts what I call the myth of the volunteers - a long-standing popular and to some extent scholarly interpretation that perceives the volunteers as lower-class, social outsiders of a criminally inclined or mentally unstable nature. Instead this article demonstrates that these men held a distinctly European outlook and were characterised by a high level of education, intellect and their strong personal character. Moreover, they had with few exceptions developed a longing for a radical reorganisation of the European political, social and economic landscape before joining the Waffen-SS. This longing was amplified by what these men perceived as a threat to the core of European civilisation coming not only from the Bolshevik East but also from the Anglo-Liberal West.
\end{abstract}

In the late I930s, when the Danish publishing house Thanning and Appel sought a translator for Ernest Hemingway's latest book, The Torrents of Spring, they chose the young Danish author, traveller and Hemingway-enthusiast Flemming HelwegLarsen. Helweg-Larsen authored several popular books and articles in the late I93Os and early I940s, including a recollection of his travels in South America over a period of four years, Med 60 Pesos til Syd-Amerika. He was a worldly, well-educated and

\footnotetext{
University of Lucerne, Frohburgstrasse 3, 6002 Lucerne, Switzerland; martingutmann@gmail.com The research of this article was assisted by a Council on Library and Information Resources Mellon Fellowship for Dissertation Research in Original Sources and an American Scandinavian Foundation grant. The writing of this article was assisted by a New Faculty Fellows award from the American Council of Learned Societies, funded by the Andrew. W. Mellon Foundation. The author would like to thank the three reviewers for their helpful feedback.
} 
well-read young man and spoke several languages fluently. ${ }^{1}$ When not travelling or writing books, he worked as a journalist and editor in Copenhagen. Except for his remarkable word-crafting abilities and passion for adventure, Helweg-Larsen was, until I94I, an average middle-class, stable and well-integrated member of Danish society. He was not a member of the Danish National Socialist Party (DNSAP) nor did he have any contact with other right-wing political groups. But later that year Helweg-Larsen volunteered for the armed wing of the Nazi organisation, the WaffenSS. He rose through the ranks of the junior officer corps, became an influential war correspondent and, after fighting on the eastern front, was posted to Denmark where he participated in the wave of terror unleashed by the SS in late 1943 to discourage further Danish resistance and sabotage. He was arrested at the end of the war and executed as the first of 46 Danish collaborators on 5 January I946.

Helweg-Larsen was only one of thousands of men from the neutral countries of Scandinavia and Switzerland who volunteered their services to a foreign, racist and murderous regime during the Second World War. This phenomenon, though acknowledged in the historiography of the war in both Germany and the individual countries from which the volunteers came, has been explained with a rather flimsy assertion that those non-Germans who fought willingly for the Nazi regime were either criminally inclined or mentally unstable. Put differently, scholars and popular memory alike have attempted to isolate the volunteers from the rest of society by locating traits that both explain their decision to join the German side and that preclude them from being regarded as normal citizens. ${ }^{2}$ A 'normal' Swede or Dane would not have volunteered to fight for Germany, so this logic holds. This interpretation formed immediately after the war as a necessary parallel to what scholars have termed 'the myth of resistance'. In coming to terms with years of Nazi hegemony and faced with possible accusations of complicity at numerous levels and in different capacities, Western European countries developed what scholars have called a myth of resistance which exaggerated the small and insignificant anti-Nazi resistance movements. The post-war period was rife with myth-making in Western Europe, as governments and people scrambled to make sense of the humiliation of German dominance and the emergence of the post-war world order. As Tony Judt writes,

Most Europeans experienced the war passively... The only source of collective national pride were the armed partisan resistance movements that had fought the invader - which is why it was in western Europe, where real resistance had actually been least in evidence, that the Myth of Resistance mattered most. ${ }^{3}$

Similarly, Lars Breuer and Isabella Matauschek write in the case of Denmark that, "The construction of a "passive resistance" of the population which stood side by

1 Bundesarchiv Berlin [BA], SSO 83A.

2 See discussion below for examples of such works.

3 Tony Judt, Postwar: A History of Europe since I945 (New York: Penguin, 2005), 4I. See also Robert Paxton, Vichy France: Old Guard and New Order, 1940-1944 (New York: Cambridge University Press, 200I). 
side with the "active resistance" has allowed the overwhelming majority of Danes to include themselves in the resistance." The myth of resistance, which not only exaggerated the size and relevance of resistance movements but also carried the implication that the masses had been fundamentally and consistently opposed to National Socialism and the New Order, was necessarily dependent on what I call the myth of the volunteers. In the occupied countries, the numbers of volunteers heavily outweighed resistance fighters. In the case of Denmark, for example, between 6,000 and 8,00o men served in the Waffen-SS, while fewer than $\mathrm{I}$,ooo joined the resistance. ${ }^{5}$ Skewing this balance further are the roughly 6,000 Danes who volunteered for the Waffen-SS but were not accepted and the thousands who served in non-Waffen-SS armed units, such as the Schalburgkorps. If the few hundreds who had picked up guns and dynamite against the Germans were to serve as a symbol for the entire nation then the several thousands who had fought with the Germans needed to be discredited. In Sweden and Switzerland, both unoccupied throughout the war and hence with a complete lack of armed Nazi resisters to their credit, the myth of resistance, as Judt calls it, took a different form; a 'militarisation' of the popular memory of the war quickly developed which held that the essence of the countries' wartime experience had been their military preparedness to repel a German attack. ${ }^{6}$ Swiss soldiers who had guarded the border became not mere Swiss patriots but anti-Nazis and came to represent all Swiss. Hence the Scandinavians and Swiss who had joined the WaffenSS, sworn an oath to Hitler and executed Jews in trenches on the eastern front were not compatible with the myths of resistance that developed in these three, and many other Western European countries. ${ }^{7}$ And hence these men came to be considered unrepresentative of their societies.

The Swiss volunteer Eugen Wipf is a case in point: the name of Wipf, whose story has been retold in countless books and newspaper articles, has become infamous in Switzerland. Wipf began the war in the Swiss army but was repeatedly arrested for excessive drinking and running up debts. In the summer of I940 he escaped and fled to Germany where he was coerced into joining the Waffen-SS. After numerous disciplinary problems Wipf deserted. He was caught and sent to a concentration camp. Rising through the ranks of the inmates, Wipf eventually became a feared Kapo and

${ }^{4}$ Lars Breuer, Isabella Matauschek, “'Seit I945 ist ein guter Däne demokrat”: Die deutsche Besatzungszeit in der dänischen Familienerinnerung, in ed. Harald Welzer, Der Krieg der Erinnerung: Holocaust, Kollaboration und Wiederstand im Europäischen Gedächtnis (Frankfurt: Fischer, 2007), 79.

5 Jon T. Lauridsen, De Danske Nazister (Københamn: Kungelige Bibliothek, I995), 22.

${ }^{6}$ Luc Van Dongen, 'Swiss Memory of the Second World War in the Immediate Post-War Period, I94548', in ed. Georg Kreis, Switzerland and the Second World War (Portland: Kass, 2000), 270. Stig Ekman, Sweden's relations with Nazism, Nazi Germany, and the Holocaust (Stockholm: Universitet Stockholm, 2003).

${ }^{7}$ Examples of these volunteers witnessing and participating in executions are numerous. See, for example, Förhör med Kurt Lundin, 24 December 1943, Riksarkivet Stockholm-Arninge, [RASA], Säpo PA, Kurt Lundin; PM Juhlin-Dannfelt to Chefen för Försvarsstabens Underrättelseavdelning, 29 Oct. I94I, E II: I8, vol 5-6, Westberg Private Archive, Sundsvall [WPA]. 
beat several prisoners to death. ${ }^{8}$ In 1948 a former inmate recognised Wipf and he was tried by a Swiss court and sentenced to twenty years incarceration. Though Wipf is hardly representative of the Swiss men who joined the Waffen-SS, this is how he is remembered. Even the most thoroughly researched book into the phenomenon of Swiss Waffen-SS volunteers bears Wipf's name in the title. ${ }^{9}$

In Denmark, Sweden and Switzerland the phenomenon of Waffen-SS volunteers is most often explained by extreme, anecdotal examples of Wipf and his like. In Denmark, the most famous volunteer is Sören K., a man who grew up in the isolated confines of the Danish National Socialist movement and whose stint in the Waffen-SS was punctuated by murder so heinous that even the SS hauled him in front of a judge. Similarly, in his best-selling book on the Swedish volunteers, journalist Bose Schön squeezes every volunteer into one of two moulds. Either the Waffen-SS volunteer had grown up in a troublesome home, had problems with the law or the armed forces and generally led a dysfunctional, anti-social life before 'fleeing' to Germany or he had grown up a hate-filled Nazi within the isolated confines of the Swedish national socialist youth groups and parties - Schön compares these latter examples to weeds within Swedish society. Men such as Wipf and K. are remembered while the stories of men such as Helweg-Larsen, which do not conform to the myth of the volunteers, are forgotten.

Beyond these popular accounts, the academic literature on the subject has unintentionally upheld the myth. Mark Gingerich, Kenneth Estes and Rolf-Dieter Müller's works examine the phenomenon from the German perspective - why and how the German SS leadership recruited and integrated non-German volunteers. ${ }^{10}$ Because of their focus on the regime, these books do not elucidate fully who these non-German men were, why they volunteered and what they experienced during their service. Instead these otherwise thorough works unintentionally uphold the post-war myth by writing the men off as non-actors of sorts - men lacking either the will-power or the intelligence to resist Nazi manipulation. ${ }^{11}$ Gingerich, for example, writes that most Germanic volunteers saw themselves as normal fighters, not political soldiers, who quickly became disgruntled with their Nazi masters and, if possible, returned home and discouraged others from joining the Waffen-SS. ${ }^{12}$ George Stein, in his landmark study of the Waffen-SS refers to Germanic volunteers by the loaded

\footnotetext{
${ }^{8}$ Linus Reichlin, Kriegsverbrecher Wipf, Eugen: Schweizer in der Waffen-SS, in deutschen Fabriken und an den Schreibtischen des Dritten Reiches (Zurich: Weltwoche, I994), 69-7I.

9 Ibid.

${ }^{10}$ Mark Philip Gingerich, 'Toward a brotherhood of arms: Waffen-SS recruitment of Germanic volunteers, I940-I945', PhD. thesis, University of Wisconsin-Madison, I99I; Kenneth Estes, $A$ European Anabasis: Western European Volunteers in the German Army and SS, 1940-1945 (Gutenberg-e: Columbia University Press, 2003), Rolf-Dieter Müller, An der Seite der Wehrmacht: Hitlers ausländische Helfer beim 'Kreuzzug gegen den Bolschewismus, 1941-1945' (Berlin: Christoph Links, 2007).

${ }^{11}$ Estes, A European Anabasis, ch. 2: 'Crusade and Propaganda', I-2, http://www.gutenberg-e.org/eskoI/ frames/fesko2.html (accessed 30 July 20I3).

${ }^{12}$ Gingerich, 'Toward a brotherhood of arms', 275, 85 .
} 
term 'youngsters'. ${ }^{13}$ Alternatively, works which examine the more prominent and clearly intelligent Waffen-SS members reduce these men to fanatics, men infected with a virulent ideological bug which is incomprehensible in relation to and isolated from their mainstream societies. ${ }^{14}$

Only in the last few years have historians begun to challenge this reading of the foreign volunteers. ${ }^{15}$ In 2004, the Norwegian historians Terje Emberland and Berndt Roughtved published a biography of a high-ranking Norwegian Waffen-SS officer, Per Imerslund. In this work Imerslund, who had been remembered in Norway as a maniacal, fanatical Nazi by the mainstream and as a hero of upstanding character by apologists, instead emerges as in many ways a typical Norwegian, a gifted author and a seemingly contemplative and rational man who becomes complicit in gruesome crimes on the eastern front - acts which he rationalises with complex logic and his fascist leanings. ${ }^{16}$ In 2008, Michel Kirkebæk published a similar biography of Christian Schalburg, commander of the Danish Waffen-SS Legion, the Freikorps Danmark, until his death in I942. The book caused a sensation as Denmark was confronted with the fact that Schalburg, who had been a convinced Nazi, complicit in numerous acts of brutality and whose name was attached to the most notorious SS terror squad in Denmark, the Schalburgkorps, had been a respected, innovative and influential Danish officer in the pre-war years and a close friend of the royal family. ${ }^{17}$ Similarly, the I998 book by Claus Christensen, Niels Poulsen and Peter Smith on Danish volunteers offers some excellent insights into the men and their motives. ${ }^{18}$

This article builds on these studies to formulate a more nuanced and demythologised sketch of the volunteers' pre-war background by an examination of the biographies of the neutral Waffen-SS officer corps volunteers. The case for singling out Denmark, Sweden and Switzerland is multifold. Switzerland and Sweden were unoccupied. While Denmark was of course militarily occupied by Germany, its government maintained a more or less free hand in terms of internal policies until I943 by which point all the volunteers of this study had made their fateful decision. There was as such no forced conscription into the Waffen-SS as in other occupied countries. Thus a focus on volunteers from these three countries allows us to largely rule out classical, pragmatic collaboration as a motive for joining. Moreover, though

${ }^{13}$ George Stein, The Waffen SS : Hitler's elite guard at war, 1939-1945 (Ithaca, NY: Cornell University Press, I984), I40.

${ }^{14}$ Reichlin's description of Franz Reidweg and the characterisation of K. B. Martinsen by Christensen et al. fits this mould. See Reichlin, Kriegsverbrecher, passim.

${ }^{15}$ A notable exception is Søren Schou, De danske Østfront-frivillige (København: Suensen, I98I). Written several decades ago, however, Shou's work suffers from a lack of quality sources (see, Lauridsen, De Danske Nazister, 25-6.)

${ }^{16}$ Terje Emberland and Bernt Rougthvedt, Det Ariske Idol: Forfatteren, eventyreren og nazisten Per Imerslund (Oslo: Aschehoug, 2004).

${ }^{17}$ Mikkel Kirkebæk, Schalburg: en patriotisk landsforraeder (Copenhagen: Gyldendal, 2008). See, for example, Rasmus Wiin Larsen, 'Nazibøger vælter ud fra forlagene', Politiken, 28 Feb. 2008, http://politiken.dk/ boger/article608449.ece (accessed 26 July 20I3).

${ }^{18}$ Christensen, et al., Under Hagekors. For a similar analysis in the Swedish case, see Lennart Westberg, Lars Gylenhaal, Svenskar i krig (Stockholm: Historiska Media, 2005), 233-54. 
these men were far from 'unpolitical' or 'neutral', they used this later term with disdain to describe their countries' role in the international community - thus using the label to describe their national origin seems appropriate. In addition, because the countries were able to act independently, their national police and military intelligence units were able to keep careful records of their volunteer nationals, an indispensible source for this article. In fact, sources have been one of the major weaknesses of the most prominent studies of the Germanic volunteers. Most studies have relied on German, 'institutional' sources - that is the records left behind by the Waffen-SS. ${ }^{19}$ While how the SS leadership integrated, educated and employed Germanic volunteers can best be answered by examining these sources, they are less useful in understanding the individual volunteers as their thoughts were both inaccessible and uninteresting to the Waffen-SS bureaucracy. Instead this article, in addition to employing the traditional German sources, draws on detailed biographical information from some one hundred officer corps volunteers from Sweden, Switzerland and Denmark, as well as a sampling of several dozen more (out of a total of nearly 300 examined), compiled from nineteen archives in seven different countries. ${ }^{20}$

Of the I0,000 neutral SS volunteers, roughly 8,000 - the overwhelming majority - were Danes. In contrast, some I, 300 were Swiss and roughly 300 Swedish. These numbers are hard to establish with any certainty and estimates in various works, and indeed among the statistics of the SS, vary widely - there may in fact have been many hundreds more than my estimate accounts for. Additionally a few points must be made regarding these numbers and the influence of geographic and political variables on them. The low Swedish number, which could be interpreted as a lack of interest among the Swedes for service in the Waffen-SS, is more likely a result of the great difficulty of crossing the border to Norway or Finland without being caught by the border police. In the files of the local police districts in Sweden, there are hence an unknown number of documented foiled crossings and there are no doubt a higher number of aborted crossings by potential volunteers who were dissuaded by their inability to leave Sweden. In one particular incident in I942, the Swedish police apprehended four Swedish volunteers which, according to an SS assessment, persuaded another 250 committed volunteers to abandon their plans. ${ }^{21}$ The border between Switzerland and Germany, by contrast, is flatter and more densely populated, making an illegal crossing easier than in the Swedish case - though by no means straight-forward as the Swiss police managed to halt a number of illegal

\footnotetext{
${ }^{19}$ Estes, A European Anabasis; Gingerich, 'Toward a brotherhood'; Berndt Wegner, Hitlers politische Soldaten, die Waffen-SS I933-I945 : Studien zu Leitbild, Struktur und Funktion einer nationalsozialistischen Elite (Paderborn: Schöningh, I982).

${ }^{20}$ Author's detailed biographical spreadsheet of one hundred men, as well as incomplete information on an additional two hundred, compiled from nineteen archives but primarily from records in BA SSO; RASA, SÄPO PA; Riksarkivet Stockholm [RAS]; Krigsarkivet, Stockholm, MUST; Bundesarchiv Bern [BAR], E 200I E I968/78 Bd. I58-59; Bundesarchiv Ausenstelle Ludwigsburg, B I62; Rigsarkivet Copenhagen [RA], RIAD I349/II; Kongelige Bibliothek, Copenhagen [KB]; Bundesarchiv-Militärarchiv [BAMA], RS 5/979, 98I-982; WPA; Archiv für Zeitgeschichte, Zurich [AfZ], NL; National Archives and Records Administration [NARA], T-I76.

${ }^{21}$ Berger to Himmler, I2 Oct. I942, NARA, T-I75/66, 2582546.
} 
border-crossing attempts. Finally, in the Danish case, there were no legal restraints to joining the Waffen-SS. Indeed the SS set up a recruitment office and the Danish corps of the Waffen-SS was sanctioned by the government.

Although there were thousands more Danes than Swiss or Swedes who volunteered, what is striking is that the number of highly motivated and intellectual volunteers who came to the Waffen-SS early and gravitated towards front line duty as well as administrative work was roughly the same. ${ }^{22}$ Of the roughly Io,ooo men who volunteered from these countries, some I,00o joined the Waffen-SS officer corps or, in some cases, while failing to achieve a higher rank were given leadership roles either in combat or in the SS bureaucracy. The number of neutral SS officers working for the Germanische Leitstelle, for example, the main SS office tasked with integrating and conceptualising the use of Germanic volunteers, was comparable from each country, with slightly more Swiss, not Danes. This suggests that there was a core group of men in each of these countries who were willing to get to Germany by any means possible, which in the Danish case proved quite easy, in the Swiss case somewhat more difficult and in the Swedish case thoroughly challenging. The excess thousands of volunteers from Denmark and hundreds from Switzerland may have been the stereotypical young, impressionable, adventurous types who in the Swedish case simply stayed at home. By examining officer corps volunteers, as well as the few who held leadership positions without an official rank, however, this article aims to show that while the neutrals who joined the Waffen-SS as regular soldiers may have been uneducated social 'losers' and deviants, drawn by naivety or greed - a conclusion that itself is not supported by more recent literature, such as Christensen, et al. - there existed above them a significant number of well-integrated and educated men who left for Germany with an active interest in contributing both physically and intellectually to the Nazi project.

What emerges upon a detailed examination of these men's biographies is not one unifying and exceptional characteristic but a multitude of individual stories of diverse men who shared a similar social origin, outlook, personality traits and ideological inclination. While they were alienated and came to be regarded as traitors during the course of the war - immediately in the Swiss case - they had not, with few exceptions, been alienated before the beginning of the war. Like Helweg-Larsen, most of these men were highly intelligent but adventurous men who were well integrated in their pre-war societies. In fact, if one chooses to regard Helweg-Larsen and his cohorts as deviating from the average then surely they fall above not below this arbitrary mark, at least in terms of education, worldliness, social integration and ambition. If one were to tease out a rough representative profile of the volunteers of this study, this man would firstly be of a middle or upper-class upbringing, welleducated and integrated into his society. Moreover, he would have a cosmopolitan

\footnotetext{
${ }^{22}$ The Swedish volunteer Thorolf Hillblad too noticed during his service that the 'neutral' volunteers were unique among all the Western European volunteers because of their political work. See, Hillblad undated notes from SS-Junkerschule Bad Tölz [presumably Spring I943], RAS, SE/RA/72II268 and Schön, Hitlers svenska soldater, 83. See also Eijnar Vaaben to Hillblad, 25 February I944, RASA, SÄPO PA Thorolf Hillblad.
} 
outlook or an openness to the wider world, evident through frequent travels, studies abroad, international reading and writing interest, and the ability to speak several foreign languages. Furthermore, his superior officers, both at home and in Germany would describe him as deeply ambitious, superbly confident, adventurous and quick to take action. Finally, this man, though at best ambivalent towards the German National Socialist party and its programme, would have what can be best described as an ideological inclination towards fascism with an imbedded pan-Europeanist tension. Through his travels, he would have developed both a love of his home and aspirations towards a community above the nation. He was at once a nationalist and an internationalist. His pre-war history would further betray a desire to both move beyond the confines of many of his society's traditions, especially those inherited from the French Revolution, and reclaim the 'purity' of his nation. Spawned from their disgust with what they perceived as their countries' and the West's stagnation in culture, politics and economics, and the perceived threat from both the Bolshevik East and the Anglo-liberal West, they wished for a new form of organisation for what they saw as the heartland of European civilisation. Though not fully articulated in all these men, the seeds of such a world-view and of such a longing were present long before they donned the Waffen-SS uniform.

The extent to which an individual is integrated into a society is perhaps best measured by his work and professional relationships. Several of the volunteers had reached influential positions within academia, government, industry or the armed forces. Helweg-Larsen, as we have seen, was a well-known author in Denmark as was Folke Nystrand in Sweden. ${ }^{23}$ The Swiss lawyer Heinrich Büeler had his practice at the most prestigious - and expensive - address in Switzerland, the Bahnhofstrasse in Zurich. ${ }^{24}$ K. B. Martinsen, a gifted young Danish officer, graduated at the top of the I93I-3 Danish officers' academy class and was a few years later invited to partake in general staff training, the highest military academy in the Danish Army. ${ }^{25}$ In 1936 he was sent as the Danish representative to the Non-Intervention Committee military observers in the Spanish Civil War. ${ }^{26}$ His colleague Christian Schalburg was an instructional officer in the Danish army's infantry school and a leading officer in the royal guards, the Kongelige Livsgarde. ${ }^{27}$ A natural and respected leader, Schalburg's militer peedagogig greatly influenced Danish infantry training for decades to come and caused most of his men, including those who would later fight in the Danish resistance against Schalburg's namesake SS-terror squad, Schalburgkorpset, to comment after the war that he was by far the best officer they had ever encountered. ${ }^{28}$ Schalburg and his wife also became close friends with the royal family, especially King Christian X's brother, Prince Gustav. ${ }^{29}$ Like Schalburg, the Swedish officer Gösta Borg served

\footnotetext{
${ }^{23}$ Nystrand achieved true fame only after the war.

${ }^{24}$ See correspondence in AfZ, NL Büeler, 3.

${ }^{25}$ Hærens Offficersskole, 4/9 I933, KB, Acc. 2008/8, K. B. Martinsen, II.

${ }^{26}$ Ibid. Commission Internationale de Non-Intervention en Espagne, 3I Aug. I938.

${ }^{27} \mathrm{BA}, \mathrm{SSO} 69 \mathrm{~B}$.

${ }^{28}$ Kirkebæk, Schalburg, 70-8.

${ }^{29}$ Ibid. 63.
} 
in the Swedish royal guards, Svea Livgardet. ${ }^{30}$ Several Swiss volunteers also served as high-ranking officers in the militia army.

Similarly, and further representative of their integration and their general intellect, the level of education of most of these men was well above the average. Over $85 \%$ of the one hundred sampled in detail had attended university or another trade, technical or military higher education institution. Fifteen of the men held doctoral degrees. Those who had not been afforded higher educational opportunities nevertheless displayed great intelligence and general knowledge. The Swede Gösta Borg, for example, had grown up in a lower-class home in Stockholm; his father was a stonemason. Borg left school at the age of fifteen. ${ }^{31}$ Yet his instructor during his Waffen-SS officer course at Tölz remarked that, 'in spite of his modest schooling he exhibits good general knowledge and strives constantly to expand his knowledge'. ${ }^{32}$ Moreover, Borg, who was a professional soldier in the Swedish army with a stint in the Swedish volunteer force in Finland, could have continued his education in the Swedish officer academies had he not chosen to volunteer for the SS. Indeed when Borg left for Germany in 1942 he was enrolled as an officer cadet at the military academy in Karlberg where he received the highest marks of his class before departing prematurely. ${ }^{33}$ Taking into account that those few volunteers who had not graduated from higher institutions, like Borg, were firstly younger and secondly, judging by their assessments within the SS, intellectually quite capable along with the fact that most volunteers had in fact many years of upper level study behind them suggests that this group of men was intellectually above average.

Equally notably, most of the men came from middle or upper class households (roughly $75 \%$ of those sampled). Most had been born into this class though some had reached this status through education and hard work This is suggested firstly by their education but more conclusively shown by their professions, as well as those of their fathers. The statistics of their own pre-war employment compared to that of their fathers shows the fact that some managed to climb beyond their social origins. Borg and Martinsen, for example, are two such examples of men of a humble background who rose to respectability, in both cases through the armed forces. It is also significant to note that the middle-class origin and particularly the high level of education of these men is not a mere reflection of Waffen-SS officer standards. Unlike the Wehrmacht, the Waffen-SS did not discriminate by education or social origin in selecting its officer candidates and so did not even require a candidate to have graduated with a high school (Gymnasium) diploma. ${ }^{34}$ In fact Berndt Wegner's detailed investigation of the composition of the German Waffen-SS officer corps reveals a high number of people who had improved their social position, especially by the second half of the war. ${ }^{35}$ The neutral men of the

\footnotetext{
${ }^{30}$ Stockholm Polis, I5 May I945, RASA, SÄPO PA Sam Gösta Borg.

${ }^{31}$ Ibid. Protokoll over förhör, I2 May I945.

${ }^{32}$ Allgemeine Beurteilung, BA, SSO 9I.

${ }^{33}$ Westberg and Gylenhaal, Svenskar $i$ krig, 269.

${ }^{34}$ Laufbahnbestimmungen, I6 June I94I, BA, NS 33/46.

${ }^{35}$ Wegner, Hitlers Politische Soldaten, 26I.
} 
Waffen-SS officer corps, then, appear overall to have come from higher social backgrounds than their German Waffen-SS counterparts. ${ }^{36}$ Instead, judging by their education, profession and father's profession, they match the profile of the average German Wehrmacht officer very closely. ${ }^{37}$ Gottlob Berger, head of the SS Main Office, too, noticed the great extent to which Germanic Waffen-SS officers, unlike their German counterparts, came from a 'bourgeois environment'. ${ }^{38}$ Indeed, as we will see, the ills of the 'bourgeois environment' in which they had grown up is one of the things many of these men hoped to combat with their service in the Waffen-SS.

What further supports the conclusion that these men came largely from reasonably wealthy circumstances is the extensive travel many of them undertook in the prewar years - though exact figures are hard to procure, as the absence of a record of travel does not preclude it from having taken place. The anecdotal evidence is overwhelming, however. In the biographies of these men, their travels, language skills, studies, relationships and personal reflections testify to an openness to experiences outside their national cultures and traditions - though as we will see, this 'openness' was limited by their fascist leanings. This is obvious in the cases of the Swiss Max Leo Keller and Helweg-Larsen but is prevalent among the other volunteers as well. The Swede Sigurd Baecklund, son of a professor and himself a university student, visited the United States of America, England, Norway, Denmark, Germany, Russia, Finland, Estonia, Lithuania, Czechoslovakia, Italy, Bulgaria, France, Spain and Switzerland, all without the accompaniment of his parents between the ages of seventeen and twenty-four. He was fluent in four foreign languages. ${ }^{39} \mathrm{His}$ countryman, Hans-Caspar Krueger, in addition to Swedish and German, spoke English, French, Spanish and Russian. Keller worked to overhaul the energy grids of several American and European cities in the I930s. The civil-engineer Gustaf Ekstöm spoke German, Norwegian, Danish, Finnish, French and English, in addition to his native Swedish. ${ }^{40}$ The Swiss Heinrich Weichlin visited fifteen European countries in the 1920 and 30 during his $\mathrm{PhD}$ studies and as part of his work as a journalist. ${ }^{41}$ After studying theatre, art and economics in Berne and Berlin, Johann W. took a position as a theatre director in Riga. ${ }^{42}$ The Danish officer Martinsen commanded French at a most nuanced level, as well as English and German. ${ }^{43}$ Many of the volunteers were also born abroad. The Swiss lawyer Heinrich Büeler, born in Cochin in British

\footnotetext{
${ }^{36}$ Compare German Junkers in the 'IIth wartime officer training course' with Germanic Junkers in the parallel '3rd Germanic officer training course': SS-FHA, Sonderverteiler, II. Kriegsjunkerlehrgang, I4 March I944, BA, SSO AI4, 2578-I584 and Sitzliste, BAMA, RS 5/327 and matching individuals' personnel files in BA, SSO.

${ }^{37}$ Bernhard Kroener, “"Menschenbewirtschaftung”, Bevölkerungsverteilung und personelle Rüstung in der zweiten Kriegshälfte (I942-I944)', in ed. Bernhard Kroener, Rolf-Dieter Müller and Hans Umbreit Das Deutsche Reich und der Zweite Weltkrieg: Band 5.2 (Stuttgart: Deutsche Verlags-Anstalt, I999), 865.

${ }^{38}$ Speech at Luftfahrtministerium, Berlin, Feb. I944, BA, NS 33/213.

${ }^{39}$ Sigurd Baecklund, Beurteilung Tölz, BAMA, $\mathrm{RS}_{5} / 983$.

${ }^{40}$ Schön, Hitlers svenska soldater, 92. BA, PK C50, Ekström, Gustaf.

${ }^{41}$ Weichlin to Büeler, 2I Oct. I94I, AfZ, NL Heinrich Büeler, 4.I.

42 'Urteil des Bundesstrafgerichts in Sachen Franz Riedweg und I8 Mitangeklagte', I67, BAR, E 4320 (B), I984/29.

${ }^{43}$ Realexamen Maj-Juni I923, KB, Acc. 2008/8, II.
} 
India, studied in Paris and Hamburg, as well as in various cities in Switzerland. He was fluent in English, Dutch, German and French. ${ }^{44}$ His countryman Friedrich Weilenmann grew up in Bucharest. ${ }^{45}$ Schalburg grew up in Russia until his Danish aristocratic family fled home in the face of the Bolshevik Revolution. ${ }^{46}$ The Swedish doctor Olaf Jürgenssen was born in Vladivostok, Russia and in 1936 decided to pursue his medical studies in Germany within the framework of the Waffen-SS. ${ }^{47}$ In cases where an individual did not travel abroad extensively in the pre-war years, a deliberate, but unsuccessful, effort to do so can be observed in many cases. The Swede Hans-Gösta Pehrsson, for example, sought consistently to gain employment in Buenos Aires during the I930s. ${ }^{48}$ Others, it appears were too young and had not yet completed their studies by the time the war broke out, thereby robbing them of a chance to travel abroad.

Beyond this sampling of biographies, the truly uncanny linguistic abilities of most of these men is further highlighted by their evaluations at the Waffen-SS officer training school at Tölz. For example, of Sigurd Baecklund's twenty-one Germanic classmates in the IIth Kriegsjunkerlehrgang, eleven spoke two or more foreign languages fluently - neither German nor their native language was considered a foreign language by the SS evaluators. Of these, many commanded three or four such foreign languages. ${ }^{49}$ Significantly, in only one of the cases did the supervising German officers complain that a cadet spoke insufficient German by the end of the course. This is especially surprising as at this time the Waffen-SS leadership frequently complained that the command of German among many German cadets was insufficient to properly carry out the duties of a Waffen-SS officer. ${ }^{50}$ It seems, most of these men, through their travels, studies and above-average abilities were adept at adapting to new situations, including perfecting a foreign language. Indeed this ability seems to have grown from a pressing desire among these men to experience the wider world.

Though an inclination for travel is in and of itself hardly unique, the prevalence of this trait in nearly all the men where enough data is available to reconstruct their formative years is striking. It hints at an openness to explore the world and a comfort with foreign ideas and cultures. This is evident, too in the number of these men who married foreign women. Of the some Ioo officers studied in detail (out of the 300 sampled), over $60 \%$ were married - itself potentially a sign of social stability and integration. Of these, in the twenty-six cases in which it is possible to identify their partner's origin, exactly half were married to foreign women.

But beyond these statistics of travel, languages and marriages, the writings of many of these men betray a great longing for adventure, a yearning to step out of

\footnotetext{
${ }^{44} \mathrm{BA}, \mathrm{SSO}$ II7.

45 'Urteil', I69-70.

${ }^{46}$ Lebenslauf, BA SSO $69 \mathrm{~B}$.

${ }^{47}$ Lebenslauf, BA, SSO I42A. See also, Westberg, Svenskar $i$ Krig, 283.

${ }^{48}$ Malmö Polisen, 25 Oct. I945, 2, RASA, SÄPO PA Hans-Gösta Pehrsson.

${ }^{49}$ See 'Zeugnisse' and 'Beurteilungen', BAMA, RS 5/979-984.

${ }^{50}$ SS-FHA, Chef des Staabes, I5 July I94I, BA, NS 33/220.
} 
the ordinary. Helweg-Larsen for example, described in his I94I book Med 60 Pesos till Sydamerika why he decided to abandon his job and travel to South America.

I had always known the moment had to come. The existence in a slumbering office would be unsustainable in the long run ... And so suddenly one day I jumped up and knocked on the director's door and quit. I have always wanted to get out. As a boy, my favorite reading was books about the tropics and the white man's experiences. For long-drawn-out years I dreamt about getting out and experiencing the same adventures as the heroes of my books. ${ }^{51}$

Though these words may be ordinary reflections of a bored young professional, Helweg-Larsen actually acted on them. During his many years in South America, he volunteered to fight for Paraguay in the Chaco War against Bolivia. In his own words, he felt a 'tremendous desire' to fight and relished in the thought of literary inspiration from 'the war in the green hell'. ${ }^{52}$ Similarly telling, in I934, the sixteenyear-old Swede Thorolf Hillblad biked alone through Germany and back to Sweden. When this fearless teenager biked past a road sign for Oranienburg concentration camp, which he had read about in Sweden, he made the detour, pulled up to the guard booth, demanded to see the Kommandant and got himself invited to eat and spend the night with the inmates. ${ }^{53}$

Similarly to Helweg-Larsen and Hillblad, in those men who kept journals through their early adulthood a deep desire to see the world and experience raw adventure pervades their writing. During his officer training, the Dane C. P. Kryssing, for example, wrote in an essay that he wished to "escape from daily surroundings into the wide world' ${ }^{54}$ Büeler, the Swiss lawyer, displayed a similar restlessness in the face of respectable life. In his twenty-page apologia, written while imprisoned in Switzerland in 1947 his opening statements concern just this trait.

I was never in my life a person who would simply love an idea for its own sake. I always tried to bring thoughts to living expression ... I was always a seeker, even though I came from a proper bourgeois upbringing - perhaps this is exactly why I became so. The bourgeois environment never satisfied me; even later when I had a good legal practice and a good marriage, I never found my inner balance." 55

Büeler's sentiment of needing to 'bring thoughts to living expression' and his restlessness exemplify the desire among the volunteers to not merely advance ideas intellectually but to partake in their physical creation, the extent to which they saw themselves as both 'thinkers' and 'doers'.

What is particularly important to note, too, is that neither Switzerland, Sweden nor Denmark had a significant colonial history. ${ }^{56}$ In Britain, France and even Belgium, men with such cravings as Büeler's would likely have found their way into colonial administration and forces. Moreover, as these men would comment

\footnotetext{
${ }^{51}$ Flemming Helweg-Larsen, Med 60 Pesos til Syd-Amerika (Copenhagen, I942) I9.

${ }^{52}$ Ibid. 9I.

${ }^{53}$ Notitser T. Hillblad, WPA.

${ }^{54}$ C. P. Kryssing, 3. En uhyggelig Oplevelse (I7/I2-I9II), KB, Utilg. 84I, C. P. Kryssing, II.

${ }^{55}$ Büeler letter, I5 Jan. I947, I, AfZ, NL Büeler, 8. I.

${ }^{56}$ Denmark, of course, controlled Greenland, and Sweden, a small island in the Caribbean, though these were hardly the makings of the grand empires these men envisioned.
} 
repeatedly throughout their careers, the failure of their countries to establish colonies had not only robbed them personally of a chance at adventure and glory but signified a great lost opportunity for their people - as had the failure to partake in the First World War.

Beyond their private adventures, many future Waffen-SS Swedes and Danes sought to rectify this failure by volunteering to fight against the Soviet Union in the Winter War in Finland, which broke out in late November 1939. The Svenska Frivilligakaren, Swedish volunteer force, was officially sanctioned by the Swedish government and attracted some 8,600 volunteers. ${ }^{57}$ Many of these would return to fight in the socalled Hangöbataljon when the war between Finland and the Soviet Union continued in the summer of I94I ${ }^{58}$ Of the Swedes who would later become influential WaffenSS members, nearly half had fought in Finland. Of those who had not, many had been too young. The Danish government, too, sanctioned a force, including active officers, to serve in Finland. ${ }^{59}$ Several of the I,ooo volunteers, including Schalburg, would later join the Waffen-SS. Interestingly, most of those who did not join the Waffen-SS instead joined the Danish resistance. ${ }^{60}$ This is perhaps not surprising, as men who have learned the art of organised violence would be more prone to use it again. Yet their initial instinct to join the fight in Finland was obviously not born from previous experience in combat and hence speaks to a certain personality trait - that of a person not afraid to take action, of great ambition and confidence and perhaps with an adventurous and violent inclination.

Owing to Switzerland's policy of strict neutrality and the laws against foreign military service, Swiss citizens were not given the opportunity to aid Finland in its struggle against the Soviet Union. It was exactly this 'misguided' policy of neutrality that many Swiss Waffen-SS volunteers lamented and who instead looked back at the legacy of Swiss mercenaries for inspiration. Benno Schäppi remarked repeatedly that Switzerland had lost its martial spirit and that he had a personal 'affinity with soldiering and always looked back with great admiration at the soldierly in Switzerland's history'. ${ }^{61}$

Many of the volunteers, then, could be characterised as inclined towards the soldiering life - evident in the high number of professional officers $42 \%$ of those sampled), Finland volunteers (49\% of Swedes and $32 \%$ of Danes) and in private martial adventures, such as Helweg-Larsen's experience in South America. Yet this desire cannot be understood as a mere affinity towards violence or the armed forces. For some of these men, violence appears to have taken on a redemptive quality, both personally and for their countries, as Schäppi's quote makes clear. Memoirs and diaries of those who had fought in Finland or other foreign conflicts read like

\footnotetext{
${ }^{57}$ Hans Neulen, An deutscher Seite: Internationale Freiwillige von Wehrmacht und Waffen-SS (Munich: Unversitas, I985), I62.

${ }^{58}$ Westberg, Svenskar i Krig, 244.

${ }^{59}$ See Jan Nielsen, I orkanens øje: Det danske Finlandskorps 1939-40 (København: Gyldendal, 2006).

${ }^{60}$ Christensen, Under Hagekors, 48.

61 'Schweizer in der Waffen-SS', DRS I, 5 June I977, AfZ, NL Schäppi, Dossier 6.
} 
treatises on the virtues of violence and conflict. ${ }^{62}$ The case of the Swede Erik Wallin is equally exemplary of this. Wallin, who would became a platoon leader in the so-called 'Swedish Company' of the SS Division 'Nordland' in the last years of the Second World War had joined the winter war of $1939-40$ in Finland and had returned to fight yet again during the continuation war in I94I. ${ }^{63}$ Upon returning to serve in the Swedish armed forces at the beginning of 1942 , his mother noticed a restlessness and longing for combat in her son. She wrote a letter to the police in October of I942 in which she confessed her fear that he might join the Waffen-SS. ${ }^{64}$ Before the police could act, Wallin slipped across the border and on to Germany. During his service in the Waffen-SS, he would be severely injured three times, always returning immediately to the front. In February of I945, as his Division had been pushed by the Red Army into the narrow pocket on the Courland peninsula in the Baltic, Wallin wrote to his mother that he was in Germany to "honour the Swedish colours and the old Carolinian shield'. ${ }^{65}$ Several of Wallin's Swedish colleagues served out their initial contracts with the Waffen-SS, only to return to Sweden for a few weeks before re-enlisting with the Waffen-SS, this despite the fact that by that point I943-44 - the war's successful outcome from a German point of view seemed more than doubtful and they could have expected little if any judicial consequences had they simply stayed in Sweden following their first tour of duty abroad. The need to redeem themselves and their countries from perceived decadence and decline became a pervasive element in these men, an element which would grow during the conflict as they became increasingly isolated from the populations at home and radicalised by a vitriolic ideology and the bloody realities of war.

In addition to this inclination towards viewing violence as having personal and socially redemptive qualities, many volunteers were imbued with supreme confidence, ambition and leadership qualities - again in direct opposition to the dominant imagined profile of the volunteers. These characteristics, difficult to quantify, can best be observed from their military evaluations, both from home and in Germany. The Swiss Dr Franz Riedweg, for example, was described by his front-line commander in I944 as, 'an energetic, goal-oriented person with healthy ambition'. ${ }^{6}$ Sverre K.'s evaluation upon his graduation from the Waffen-SS officer training school at Tölz referred to him as 'a very strong spirit, quick to learn, has good general education, a powerful physique, convinced and an ability to endure. He has a stronglylodged, secure character and is honest and direct. ${ }^{67}$ The Dane Erling Hallas was described by the commander of his Waffen-SS unit as a 'fiercely thinking national socialist . . . militarily clearly above the average'. ${ }^{68}$ While serving as the Danish military observer to the Spanish Civil War in France, his commanding officer of

\footnotetext{
${ }^{62}$ See, for example, G. S-, Riksarkivet Stockholm, SE/RA/72I268; Helweg-Larsen.

${ }^{63}$ Protokoll, 23 June I945, RASA, SÄPO PA Erik Wallin.

${ }^{64}$ Ibid. PM 7.I0.43, RASA.

${ }^{65}$ Wallin letter, 23 Feb. I945, WPA.

${ }^{66}$ Beurteilung über Riedweg, Franz, 8 June I944, AfZ, NL Riedweg, 3.

${ }^{67}$ Beurteilung, SS-Geb.Art.Rgt.6, Im Felde, [date illegible], BA, SSO, I74A.

${ }^{68}$ Freikorps 'Dänemark', Abt. IIa., 28 March I942, BA, SSO 55A.
} 
the non-interventionist observers characterised Martinsen as 'a good officer, with good form, intelligent, excellently schooled, enthusiastic and loyal, who does his service with a great deal of dedication, ardour and tact'. ${ }^{69}$ Another example is the Swiss Dr Wilhelm Knapp, an Oberleutnant in the Swiss armed forces and later a SS-Hauptsturmführer in the Waffen-SS. Suspected of harbouring National Socialist sympathies, Knapp was investigated by the Swiss army leadership in the spring of I940. Even in this tense atmosphere his commanding officer, while in fact implicating Knapp as a National Socialist sympathiser, added that 'he is a proper, generally welleducated officer with impeccable behaviour. Loyal as an officer, dependable and respected by troops, colleagues and superiors. His personal and military leadershipqualities warrant no reason for his removal. ${ }^{70}$ After volunteering for the Waffen-SS, Knapp's cousins described him as 'serious and goal-oriented . . . an idealist' ${ }^{71}$

That these men were gifted in many areas is illustrated by the evaluation of the Swedish Waffen-SS doctor Olaf Jürgenssen: 'Works independently and efficiently. Great work ethic. Has a clear mind, intellectually above-average, gifted speaker and is great at organising. Great ability to learn, great desire to learn and gifted with languages'. ${ }^{72}$ These words - 'goal-oriented', 'secure/strong character', 'ambitious', 'respected leader', 'willingness to learn' - are present in many evaluation of the neutral Waffen-SS officer corps volunteers. A cursory glance at evaluations of German SSJunkers quickly reveals that these words were not dispensed with abandonment by SS evaluators who seem to reserve such praise only for exceptional cases. In the eyes of their German supervisors, as well as their superiors in their native armed forces, the neutral officer corps volunteers were not weak followers but confident leaders.

With the invasion of the Soviet Union in the summer of I94I, Himmler and the SS leadership sought to rally Western Europe behind them and lure a greater number of Western European Waffen-SS recruits by painting the struggle as a 'Crusade against Bolshevism'. ${ }^{73}$ This propaganda campaign in turn became the foreign Waffen-SS veterans' main alibi after the war - they had primarily been fighting to defend Europe against the threat of Bolshevism. ${ }^{74}$ While there was clearly a strong anti-Bolshevik element in all the neutral Waffen-SS officer corps volunteers' world-view, this was by no means the single nor in many cases even the primary focus. Anti-AngloAmerican-liberalism - or more broadly anti-Westernism - formed a significant part of these men's ideological make-up as well.

Recent research on the National Socialist regime in general has similarly rediscovered the extent to which the anti-Bolshevism and anti-Semitism - that is,

\footnotetext{
${ }^{69}$ Commission Internationale de Non-Intervention en Espagne, 3I Aug. I938, KB, Acc. 2008/8 Martinsen, II.

${ }^{70}$ Rapport vom I7. Mai I940 Betr. Oberleutnant Wilhelm Knapp, BAR, E 27/4730.

${ }^{71}$ Vincent Oertle, Sollte Ich Aus Russland Nicht Zurückkehren: Schweizer Freiwillige an Deutscher Seite, 1939-1945. (Zürick: Thesis, I998), 27.

${ }^{72}$ Beurteilung des Dr. J. Olof, I3 June I944, BA, SSO I42A.

${ }^{73}$ Sönke Neitzel, 'Hitlers Europaarmee und der "Kreuzzug" gegen die Sowjetunion', in Armeen in Europa - Europäische Armeen, ed. M. Salewski (Munster: Lit, 2004), I37.

${ }^{74}$ Though such works are too numerous to cite exhaustively, Paul Hausser, Soldaten wie andere auch: Der Weg der Waffen-SS (Osnabrück: Munin, I966) is a classic example.
} 
the East - posed only half the ideological target for the regime. ${ }^{75}$ The men of this study were not merely anti-Bolshevik but instead held a complex set of beliefs about the world they lived in. In the pre-war years, most had what I refer to as an ideological predisposition towards fascism with an pan-Europeanist tinge. This worldview combined a transnational European outlook, based on a belief in the cultural and in some cases, racial - commonality of northern or 'Germanic' (though this was a term they would not have used until arriving in Germany) Europe, with a deep sense of patriotism. Though coloured by their specific national upbringings, these ideas were informed by a transnational discourse and European-wide pressures. The sense of impending demographic and racial degradation, the fear of Bolshevism and the conviction that liberal capitalism and modernisation were leading Europe towards the brink of disaster were sentiments which reached across national boundaries. ${ }^{76}$ As we have seen, though these men were with very few exceptions convinced nationalists, they travelled outside their national boundaries, both physically and intellectually. The future of their countries, they came to believe, lay not in continued isolation and neutrality, policies that had to great detriment seen their countries sit out on colonialism and the Great War, nor in greater alignment with the West.

Following the lead of many scholars of fascism who see the phenomenon not as a mere 'anti-ideology' I see the men's emphasis on this 'positive' element as significant. ${ }^{77}$ Though with few exceptions the men did not yet speak of a Volksgemeinschaft in the pre-war years, it is evident that most of them believed there to be a north-western European cultural core which had been obscured by the West and was under threat from the East - it was not only a matter of defending these core values, however, but in finding a way to actively promote them. That is, they were not merely against liberalism, Bolshevism and 'bourgeois values' but had an equally strong vision, though vague on specifics, of what should replace it. Furthermore, the struggle which was needed to make this vision a reality was a means to its end as many of these men regarded violence as regenerative and a creative act, and a redemption for their nations' years of neutrality.

In a letter to a friend written in I94I, shortly before joining the Waffen-SS, Heinrich Weichlin recalled the importance travel had on his intellectual development and the emergence of his pan-European sentiments. Traveling in Russia shortly after its conflict with Poland in the early I920s, Weichlin felt a calling towards journalism and developed a 'commitment to always examine things with my own eyes'. This commitment led him to get to 'know some is European countries in years past'. Fuelled by this curiosity and desire to understand his European surroundings,

${ }^{75}$ Adam Tooze, The Wages of Destruction: The Making and Breaking of the Nazi Economy (New York: Penguin, 2006), 665. See also M. Knox, Common Destiny: dictatorship, foreign policy and war in Fascist Italy and Nazi Germany (Cambridge: Cambridge University Press, 2000), I43.

${ }^{76}$ The fact that many European intellectuals and others perceived a cultural crisis following the First World War is a well-studied phenomenon. In the German case, see, George L. Mosse, The Crisis of German Ideology: Intellectual origins of the Third Reich (New York: Grosset \& Dunlap, I964).

${ }^{77}$ Most notably Zeev Sternhell, The birth of fascist ideology: from cultural rebellion to political revolution (Princeton, NJ: Princeton University Press, I995). 
these experiences and travels spawned a deep sense of belonging to Europe while simultaneously strengthening his Swiss patriotism. He writes, 'And so I feel first of all Swiss but secondly European. ${ }^{78}$ Similarly, Schalburg's biographer points at a 'dual-nationalism' as one of the most pronounced features of his identity. ${ }^{79}$ Among his notes from the pre-war period in his private archive is a hand-written sevenpoint programme drawn up by Schalburg in I930. Among calls for 'racial hygiene' and an end to 'secret societies' Schalburg called for 'a union of national European states, in which people respect the maxim God, King and Fatherland' ${ }^{80}$ In those men who travelled extensively beyond Europe, Helweg-Larsen being a case in point, there emerged an equally strong sense that there was a pronounced European essence which needed to be not only protected but promoted.

The fear that Europe was under threat is of course a key feature not only of the fascist regimes. Mussolini and Hitler, but also the Swedish Social Democratic government under Per Albin Hansson, spoke openly about the threat of racial degradation that a stagnant birth rate implied. The resulting efforts to protect the racial body in these countries were overtly nationally-based. In the minds of many of the future neutral Waffen-SS officers, however, this threat was perceived as equally dangerous to the European community as a whole and, moreover, the solution lay in greater, not less, inter-European co-operation. It is in this desire for a re-invigoration of Europe - Heinrich Büeler, for example, called for the "necessity of a rebirth of the European peoples' - that these men, even those who were not members of National Socialist parties, can be characterised as fascist. ${ }^{81}$ In the more nuanced investigations into the larger European phenomenon of fascism, numerous scholars, at the forefront of whom are Stanley Payne and Roger Griffin, have pointed to the 'palingenetic' impulse - that is the desire for a 'rebirth of the national spirit, culture and society' as one of the most pronounced features of fascists. ${ }^{82}$ In their palingenetic inclination then, these men were hardly unique. But it was their tinge of internationalism that set them apart from the policies of their governments and, more strikingly, separated those future volunteers who were already National Socialists in the pre-war years from their fellow members of right-wing parties who would not join the WaffenSS. Keller, a long-term member of the Swiss nationalist movement National Front, professed a hatred only for the type of internationalism which ignored the culturalrelations of peoples ('den volksfremden Internationalismus') - a view which earned him considerable criticism from his Frontist brethren who eschewed all forms of internationalism. ${ }^{83}$

The exact development of this European-ness alongside strong nationalism in the minds of these men is hard to track; surely it developed to various degrees in

\footnotetext{
${ }^{78}$ Weichlin letter, 2I Oct. I94I, AfZ, NL Büeler, 4.I.

${ }^{79}$ Kirkebæk, Schalburg, 39.

${ }^{80}$ Ibid. 40.

81 'Gedanken einer Verteidigungsschrift', AfZ, NL Büeler, 8. I.

${ }^{82}$ Roger Griffin, The Nature of Fascism (London: Routledge, I99I); Stanley Payne, A History of Fascism (Madison, : University of Wisconsin Press, I995), 5.

83 “Betr. Meine Strafklage," AfZ, NL Keller, 3.
} 
different cases. Though there were several movements towards greater European integration in the inter-war period, perhaps the most well-known of which were Richard Coudenhove-Kalegri's Pan-European Union and Aristide Briand's diplomatic initiatives, it is hard to prove that volunteers were exposed to them. ${ }^{84}$ The pervasive tension in the inter-war integration dialogue between advocates of Pan-Europeanism - a union based on equality of the various states - and the Mitteleuropa idea - a union of north-central states under some form of German tutelage - would similarly colour the pan-Europeanism of the volunteers once they arrived in Germany, though for the most part they would favour the latter version. ${ }^{85}$ During their university years, some of the volunteers had interactions with the Liberal internationalist movements - some even gravitated towards international socialism while some interacted with the German völkisch thinkers and movements. ${ }^{86}$ Through these interactions, the idea of a closer union of the northern European peoples was implanted and is clearly visible in a nascent state in the writings of many volunteers. In the pre-war years, however, this desire would in almost all cases remain far from fully articulated.

The volunteers, such as Weichlin and others, as we have seen, gained an appreciation for the wider world through their travels. Equally important were their university experiences, whether at home or abroad. In his study of the SS intellectual and administrator Werner Best and his future cohort at the RSHA, Ulrich Herbert describes the great extent to which an embryonic völkisches Denken (racial-cultural thinking) pervaded the German universities in the late I920s and early 30s, though this had a decidedly German-centric tinge. ${ }^{87}$ The volunteers exposed to this, however, took from the völkisch impulse not an exaggerated love of the narrowly-defined German peoples but the idea that all northern-European peoples were related. ${ }^{88}$ The Swiss Franz Riedweg, too, interacted with German völkisch students and brought this knowledge back with him to Switzerland after his studies in Berlin. ${ }^{89}$ Alfons Goop lamented upon returning to Lichtenstein after gaining his $\mathrm{PhD}$ at the University of Innsbruck in Austria, a hot-bed of völkisch student organisations, that, 'our Volk is lacking a spirit of social community'. ${ }^{90}$ What both those volunteers who spent time

${ }^{84}$ For a good overview of these, see Peter Stirk, 'Between Pan-Europa and Mitteleuropa: I9I9-39', in $A$ History of European Integration since 1914 (New York: Pinter, I996).

${ }^{85}$ See ibid. I8-50; J. Elvert, Mitteleuropa! Deutsche Pläne zur europäischen Neuordnung, 1918-1945 (Stuttgart, I999).

${ }^{86}$ Most noticeably, Riedweg, who would become the most influential of the Germanic volunteers as the head of the Germanische Leitstelle, was a member of the Pan-European student league at the University of Berne and a devout follower of Coudenhove before becoming increasingly influenced by more fascist conceptions of trans-national relations.

${ }^{87}$ Ulrich Herbert, Best. Biographische Studien über Radikalismus, Weltanschauung und Vernunft, 1903-1989 (Bonn: Dietz, I996), 87, 95 .

${ }^{88}$ See, for example, BA, PK C50, 389 , Ekström, Gustaf.

${ }^{89}$ Urteil des 20. Spruchkammer des Spruchgerichts Hiddesen I8. II.I948, 3, AfZ, NL Riedweg, 3.

${ }^{90}$ Speech Goop, II Aug. I935, Landesarchiv Liechtenstein, RF I56/520/6a. On the University of Innsbruck, see Michael Gehler, Studenten und Politik: der Kampf um die Vorherrschaft an der Universität Innsbruc 1918-1938 (Innsbruck: Haymon I990). Both the SS and the Swiss government treated volunteers from Liechtenstein as Swiss, thus I have as well in my analysis. 
at German universities and interacted with the völkisch movements and those who did not have in common was the emergence of a longing for a utopian Volksgemeinschaft. Some of those volunteers who did not inherit the idea of a Volksgemeinschaft from German or their native university colleagues seem to have gained it through youthful association with communist groups. Again, this conforms to an emphasis certain scholars of fascism have placed in trying to redefine the phenomenon as a more complex and widespread ideological impulse. Zeev Sternhell, in particular, has argued that fascism was not a mere 'anti-ideology' but in fact professed certain, albeit vague, goals which in many cases bore a resemblance to the communist longing for a utopia. ${ }^{91}$ A dozen future Waffen-SS members had in fact been members of communist parties in their youth. ${ }^{92}$ One of these was the Swiss lawyer Büeler, who had been a member of the kommunistischen Jugendorganization der Schweiz for four years before his 'nationalist perspective' earned him too much disfavour with his fellow members. ${ }^{93}$ This past helps explain his otherwise curious speech given to a right-wing audience in I933 entitled 'Eidgenössischer Sozialismus'or 'Swiss Socialism' The speech begins not with a condemnation of Marxism but by arguing that Bolshevism is not a true representation of Marxism - a fairly bold proclamation in front of a thoroughly anti-Marxist crowd. Finally, Büeler advocated not only a national Volksgemeinschaft but a European-wide one because, 'Switzerland's fate is inextricably linked to that of Europe. ${ }^{94}$

What emerges upon examining the ideological development of the future neutral volunteers is that while many of them were inclined towards this pan-European fascism, the views were much more fully developed in those who joined their local National Socialist movements, which was overwhelmingly the case for Swiss volunteers. The ideas of National Socialism as an ideological force supplanting liberalism's reign and combating communism, as well as the belief in an inevitable Volksgemeinschaft were most fully articulated among the volunteers who were active politically on the far right. There are exceptions. When the Swede Erik Wallin, for example, applied for a passport in order to travel to Germany and join the war effort in I94I he admitted to the Swedish police that he wanted both to satisfy his need for action and affect a decisive change in the European political landscape. ${ }^{95}$ Similarly, the fascist party-member Max Keller wrote in what is a clear Swiss, pro-German, National Socialist framework in his I939 libel suit against two Basel newspaper reporters:

Just as liberalism determined the nineteenth century, the national and social movements rising all over will determine the shape of their country's future. Just as liberalism of course also did not originate in our country yet still found its own Swiss form, so too, I believe, the national and social

\footnotetext{
${ }^{91}$ Zev Sternhell, 'Fascist Ideology', in Fascism: A Reader, ed. Walter Laqueur (New York: Penguin, I976).

${ }^{92}$ In addition to Büeler's experience see also the story G. S - in Rapport, 25 May I944, MUST, FX 2:22/3OI and of H. H- in Schön, 90.

${ }^{93}$ Lebenslauf, AfZ, NL Büeler, 5.2.

${ }^{94}$ Ibid.

${ }^{95}$ Protokoll, 29 Mar. I94I, RASA, SÄPO PA Erik Wallin.
} 
Weltanschauung will find a fitting form for our country and Volk... If we turn away from Germany, it is not the Reich but we who would be damaged, most likely we would decay and go under. ${ }^{96}$

It is also among some of these party men, though not in all, that a high degree of anti-Semitism can be found. Most of those future volunteers who were not organised National Socialist in the pre-war years - and this was roughly 50\% - spoke of their desire for some form of European unity more in terms of culture and politics and only rarely race. Not surprisingly, then, racial anti-Semitism is also found primarily among the volunteers who were organised Nazis in the pre-war years - though the question of whether they joined these movements because they were anti-Semites or they became anti-Semites after joining is hard to answer. The Swiss Othmar Maag, for example, often explicitly compared the Volk to 'a human body' which when 'operated on incorrectly ["liberalism and emancipation of the Jews"] suffers for a long time'. ${ }^{97}$ Similarly the Dane P. R. Engelhardt, who, though an organised Nazi, had a somewhat troubled relationship with the DNSAP, wrote on the same day he was accepted into the Waffen-SS that 'the people are led by the press, the press by capital and the government. The government is chosen by the people and capital, Jews have the capital.'99 Though less explicitly racialised, Engelhardt's thinking still conforms to the fantastical, conspiratorial hatred of Jews pervasive among organised National Socialists.

Above the numerous off-hand anti-Semitic and racial remarks amongst organised National Socialist future volunteers, two men stand out as particularly prolific and uncompromising in their anti-Semitism, the Dane Erling Hallas and the Swiss Dr Alfred Zander. Both men regarded themselves as the ideologues of their respective movements - the DNSAP in Denmark and the Nationale Front in Switzerland. Zander - a future Waffen-SS ideological instructor - wrote some fourteen books and a plethora of articles in the years before the war. He made it abundantly clear in most of his writings that Jews and Bolsheviks - often conflated as one corrupting entity were the primary threat to Swiss and European existence and needed to be combated with the harshest methods. ${ }^{98}$ Hallas, too, wrote and spoke of the 'Jewish problem' as a nearly all-encompassing one, responsible for every ill and called for decisive action against them. ${ }^{99}$

Even so, to see these men as simple anti-Semites, though of course in both cases this was the pervasive element of their world-view, is to see only part of the picture. Zander's writings in particular contain, in addition to hate-filled anti-Jewish accusations and threats, most of the nuanced and 'positive' ideological elements found among other volunteers as well. In 1934, for example, he published and edited a collection of writings on 'Education, Schools and Volksgemeinschaft.' In his contribution to the collection, Zander begins by outlining the dangerous decay

\footnotetext{
${ }^{96}$ Keller letter, 25. Apr. 1939, 6, AfZ, NL Keller, 3.

${ }^{97} 30 / 4$ I94I, PR Engelhardt Notitser, RA, FOARK IoIo/90a.

${ }^{98} \mathrm{He}$ wrote several pieces dedicated to such arguments, see, for example, Dokumente zur Judenfrage in der Schweiz (Zurich: Frontverlag, 1935).

${ }^{99}$ See, for example, Erling Hallas, Racekamp: Vejladning til Forsaaelse af Jodeproblemet (Bovrup: DNSAP Verlag, 194I), I45.
} 
threatening the Swiss nation and Europe at large caused by the historical 'misdevelopment' of the French Revolution, 'should European culture be overwhelmed by the chaos (cultural-Bolshevism) ? . . A Are those foreign voices correct which label the Swiss Volk as a futureless Volk of traders, bankers and hoteliers?' ${ }^{100}$ Zander, echoing the sentiment of liberalism's failure, argued that a true, communal nature of human society, only temporarily obscured, could be reawakened. The present crises and threat of Marxism was in fact just such an opportunity to correct Europe's path and work towards re-establishing a Volksgemeinschaft. The place to begin, he argued, was with education.

We are at the beginning of a new epoch. To recognise what educating [youth] in the spirit of a new Volksgemeinschaft means, the mistake of the past must be uncovered. This period, the individualistic - one could also call it the liberal - put the individual at the centre . . . [but] the human [lives naturally] in communities, in families, tribes, Volk, nation . . . the community comes first, only after that comes the individual. ${ }^{101}$

Zander's words exemplify the ideological predisposition shared by the future Waffen-SS volunteers. In his case this sentiment had developed into a fully-fledged National Socialist world-view, in others, it appeared more as a sliver of doubt about the sustainability of the current order and a creeping desire for a more organic form of social organisation. These men - those like Zander who were organised National Socialists in the pre-war years and those like Helweg-Larsen who were not - as much as they appear to differ, do so only in degree, not in substance. Moreover, all being equipped with this ideological inclination towards pan-European fascism combined with their assertive, adventurous and intellectual personalities made them predisposed towards joining any movement that seemed to be actualising their dreams. The extent to which their pan-Europeanism was informed by a racial understanding of northwestern Europe is hard to establish. Certainly some of the men were attracted to the racial hierarchy of National Socialism and the elite nature of the SS.

The ideological sketch developed above does not represent a clearly defined dogma to which all men adhered. Instead, all the men held different elements of this worldview to different degrees. In many cases, it appeared in the pre-war years as a more embryonic than a fully-fledged world-view - hence the aptness of the term 'ideological predisposition'. And such a predisposition is, of course, not enough to explain why they joined the Waffen-SS. In fact, in holding these beliefs the men differed little from thousands of their countrymen who did not volunteer for the Waffen-SS. Though the pan-European leaning and the belief that the socio-political system was malleable were particularly strong among the neutral volunteers - traits which both those who belonged to National Socialist parties and those who did not shared - their world-view built on commonly held tenets of mainstream European

\footnotetext{
${ }^{100}$ Alfred Zander, Schriften der "Nationalen Front", Heft 12,13. Jahrg., März 1934 (Zurich, I934), 6-7.

${ }^{101}$ Ibid. 7 .
} 
thought at the time. ${ }^{102}$ Similarly, neutrality, though supported by many, was hotly contested among significant groups in each country.

A careful look at the biographies of the neutral men who joined the Waffen-SS contradicts the myth of the volunteers. Far from social outsiders, the men represented intelligent and socially adept individuals. The pressing question of why men with everything to lose and little obvious to gain would join the Waffen-SS takes on a great level of complexity when the singular, exceptional and socially alienating trait of some of the older historiography is removed from the equation. Arguing, for example, that primarily weak-minded, socially and economically marginalised, fanatical Nazis or habitual criminals joined the Waffen-SS absolves a writer of conducting in-depth biographical examinations and robs these historical actors of agency. They did not make a personal decision; instead, so this logic goes, social isolation, naivety and weakmindedness dictated their joining. In reality joining the German Waffen-SS officer corps was a profound decision taken only by confident and ambitious individuals who were well aware of its potential consequences but willing to gamble for the sake of an ideal. However, why each individual eventually joined the Waffen-SS, though predisposed by the characteristics outlined in this article, is an individual story in and of itself and must be sought in each of their fateful biographies. The evidence above suggests, however, that in addition to a predisposition to fascism in the broader, pan-European sense, a restless, adventure-seeking personality was crucial in propelling many of the men to join. Regardless of their precise motives, the evidence unearthed in this article suggests very strongly that the non-German men who threw their enthusiastic support behind the most implicated branch of the murderous Nazi regime were not exclusively criminals or madmen.

\section{Le Mythe des volontaires: Le Volontariat transnational au sein du corps des officiers de la Waffen SS pendant la Seconde Guerre mondiale}

Cet article explore les antécédents, avantguerre, des Suisses, des Suédois et des Danois qui se sont portés volontaires pour les formations de combat de la Waffen SS au cours de la Seconde Guerre mondiale. Un examen biographique approfondi des officiers volontaires contredit ce que l'auteur appelle le mythe des volontaires, une interprétation largement répandue et dans une certaine mesure retenue par quelques historiens selon laquelle les volontaires étaient des marginaux, issus de milieux populaires, à tendances criminelles ou psychologiquement instables. L'article montre en effet que ces hommes avaient une vision tout à fait européenne du monde et jouissaient d'un haut niveau d'éducation et d'intelligence et d'une forte personnalité. De plus, à quelques exceptions près, ils rêvaient déjà avant de rejoindre les Waffen SS d'une réorganisation en profondeur du paysage politique, social et économique européen. Ce désir était amplifié par la menace pour l'essence même de la civilisation européenne qu'ils voyaient non seulement dans l'Est bolchévique, mais aussi dans l'Ouest anglo-libéral.

\section{Ausländische Freiwillige im Offizierskorps der Waffen-SS: Mythos und Wirklichkeit}

Zahlreiche Schweizer, Schweden und Dänen meldeten sich während des Zweiten Weltkriegs freiwillig zum Dienst in der Waffen-SS. Dieser Beitrag untersucht die Herkunft und den Werdegang dieser Männer in der Vorkriegszeit.

${ }^{102}$ See for example, Mark Mazower, Dark Continent: Europe's twentieth century (New York: A. A. Knopf, I999). 
Bei einer eingehenden Auseinandersetzung mit den Biografien der Freiwilligen kristallisieren sich deutliche Widersprüche $\mathrm{zu}$ dem in der Allgemeinheit und teilweise auch in der Wissenschaft verbreiteten Mythos heraus, nach dem es sich bei diesem Freiwilligen zumeist um kriminell veranlagte oder psychisch instabile soziale Außenseiter aus der Unterschicht gehandelt habe. Der Beitrag veranschaulicht vielmehr, dass diese Männer eine betont europäische Denkweise sowie einen hohen Bildungsgrad, einen ausgeprägten Intellekt und einen starken Charakter aufwiesen. Mit wenigen Ausnahmen ist bei allen ein Verlangen nach einer radikalen Umgestaltung der politischen, gesellschaftlichen und wirtschaftlichen Landschaft in Europa erkennbar, bevor sie sich schließlich zur WaffenSS melden. Dieses Verlangen verschärfte sich durch ihre Wahrnehmung von Einflüssen aus dem bolschewistischen Osten und dem angloliberalen Westen als Bedrohung für das Wesen der europäischen Zivilisation. 